\title{
都市鉄道整備水準指標に関する基礎的考察“
}

\section{A Basic Study on the Indicator for measuring Services and Infrastructure Developments of Urban Railways}

\section{平石 和昭 **落沼 慶正**}

by Kazuaki HIRAISHI, Yoshimasa TADENUMA

\section{1.はビめに}

海外、特に欧州の諸都市圈に比較して、日本の地方都 市圈の都市鉄道整備水準は低い。しかしながら、地方都 市圈に扔いても、「住民のモビリティの向上」はもとより、 「道路混雑の緩和」「運輸エネルギーの節約」「都市構造 の適正化」「移動制約者の交通の確保」「都市交通環境の 改善」等を目的として、都市鉄道整㣁水準の向上が要請 されている。

地方都市圈において都市鉄道サービスを改善するため の問題点の一つとして、投資の目安となる適切な整備水 準指標がないことが挙げられる。首都圈をはじめとする 大都市圈に扑てい、「混雑率」を指標として新線建設、 複々線化、車両の増設等の投資が行われているが、地方 都市圈では、地方都市圈にふさわしい新たな整備水潐指 標を打ち出すことが重要であろう。

そこで本研究では、地方都市圈に佂ける交通政策上の 重要課題であるC B Dへのアクセスに着目した都市鉄道 整㣁水潐指標を提案し、人口 50 万人以上の 29 都市圈 (東 京、名古屋、大阪の三大都市圈を除く）を対象としてそ の有効性について検討した。

次いで、この指標を用いて、札幌、仙台、広島、福岡 とドイッのフランクフルトとの間で、都市鉄道の整備水 準の試算・比較を行った。

な押、本研究でいう「都市圈」は、同一時点、同一方 法で整備された 1990 年国勢調查報告 (従業地・通学地 集計結果）による 10\%通勤・通学圈をもって定義した。

また、都市鉄道」とは、郊外鉄道、地下鉄、モノレ ール・新交通システム、路面電車等都市圈内で輸送サー ビスを提供する鉄軌道全てを含んでいる。

\footnotetext{
*Key Words 鉄道計画、都市鉄道整備水準

**正会員、(財) 運輸政策研究機構運輸政策研究所

（テ105-0001 港区虎）門 3-18-19 tel:03-5470-8415)
}

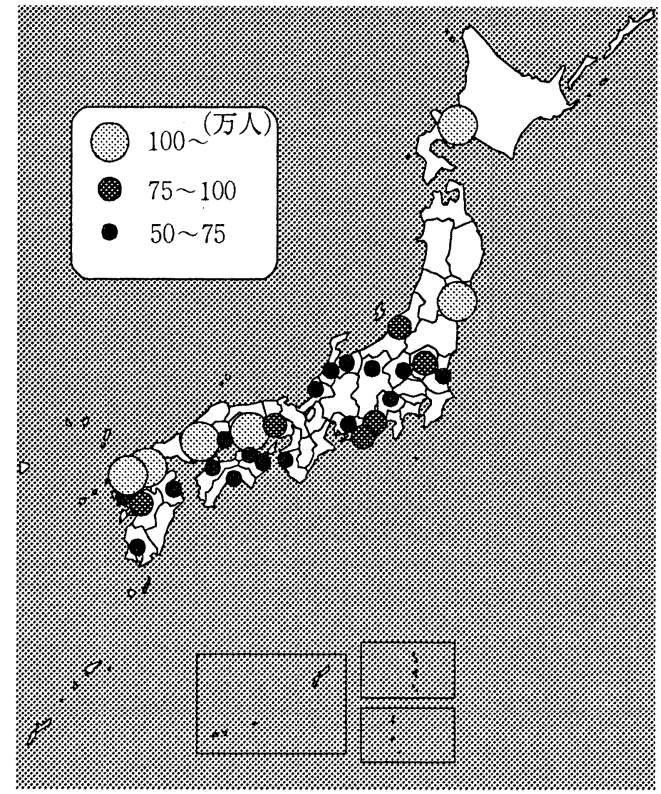

\section{図-1 対象都市圈}

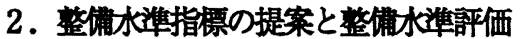

\section{（1）従来型指標の限界}

従来、マクロ的に都市鉄道の整備水準を測る指標とし ては、「人口あるいは面積あたり鉄道路線延長（路線密 度)」や「人口あるいは面積あたり駅数 (駅密度)」が用 いられてきた。しかしながら、これらの指標は、都市鉄 道の魅力度の代理指標と考えられる鉄軌道分担率の地域 的な格差を適切に表現できていない。

図一2 は、各都市圈における人口あたり駅数と鉄軌道 分担率との関係をみたものである。鉄軌道分担率は、札 幌、福岡がそれぞれ $26.8 \% 、 23.1 \%$ と $20 \%$ を超えており、 仙台、水戸、豊橋、姫路、和歌山、広島、高松、北九州 の各都市圈が 10 20\%、その他の都市圏は 10\%未満で ある。人口あたり駅数が多いほど鉄軌道の魅力度が増し、 
鉄軌道分担率が高くなることが期待されるが、図ー2は 必ずしも期待どおりの結果を示していない。例えば、人 口 10 万人あたりの駅数が 15 駅を超える富山、福井、高 知の各都市圏の鉄軌道分担率は、それぞれ9.1\%、5.0\%、 $5.5 \%$ といずれも $10 \%$ 未満となっている。都市鉄道と競 合関係にある他の交通手段の整備状況はみてはいないも のの、人口あたり駅数という指標は、都市鉄道の魅力度 を適切に表現しているとは言い難い。

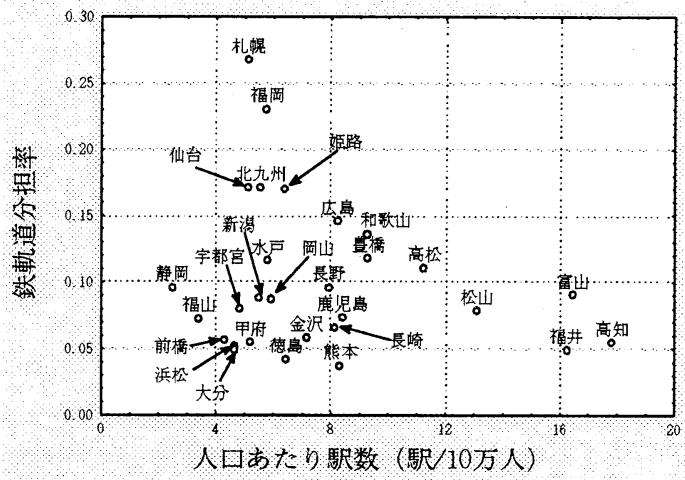

注：鉄軌道分担率は 1990 年国勢調査報告の通勤・通学交通手段デ ー夕より算出

\section{図一2 人口あたり駅数と鉄軌道分担率}

\section{（2）新たな整梢水準指䅺の提案}

そこで本研究では、1990 年国勢調査地域メッシュ統計 （基準地域メッシュ：1km メッシュ）データを用いて、 一般化費用概念に基づいた都市鉄道整備水準指標の提案 を行い、鉄軌道分担率と比較・分析することにより有効 性を確認した。

整備水準指標の提案にあたっては、CBD（Central Business District) へのアクセスに着目した。CBD、す なわち中心業務地区とは、一般に都市の中央部で事務所、 官公署、金融機関、商店、慰安娛楽施設等が最大に集中 している地区である。本研究では当該自治体へのヒアリ ングをもとに、基準地域メッシュ単位で CBD を設定し た。

地方都市圏においては、自動車交通の優位のもとで中 心市街地の空洞化が進行しているが、その再活性化を図 るためには、公共交通による圈域内各地域から CBD へ の良好なアクセスを確保することが重要な課題である。 本研究では、各都市圏ごとに、圈域内各メッシュから CBD までの鉄軌道利用による一般化費用の人口加重平均値 (住
民 1 人あたりの一般化費用）を都市鉄道整備水準指標と して提案した。所要時間および運貨・料金をマネーター ムで表現する一般化費用概念を用いたことにより、簡便 でわかりやすい指標化が可能になったと考えている。た だし、一般化費用は、都市圈面積が大きいと高くなる傾 向にあり、都市圈間比較を行う場合、面積格差が大きい 場合はその調整が必要になってくる。そのため、都市圈 の大きさを表す指標として $\mathrm{CBD}$ までの距離（直線距離） の人口加重平均值（住民 1 人あたりのC B Dまでの距離） に着目し、一般化費用をこの $\mathrm{CBD}$ までの平均距離で除 することにより、面積格差の調整を行った。

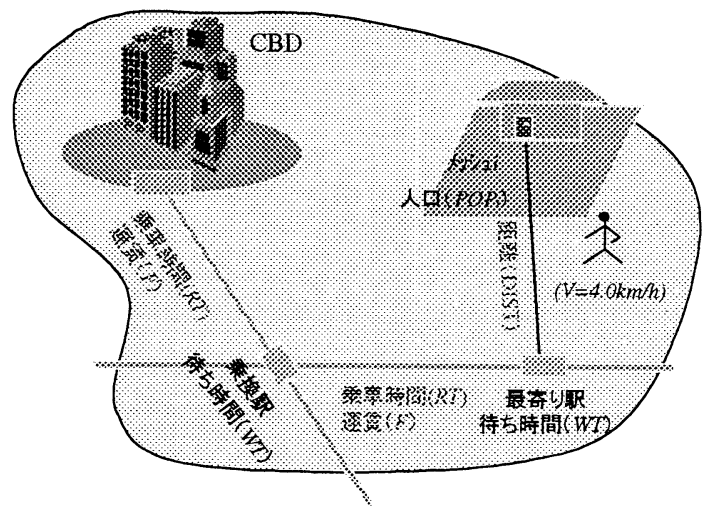

図一3 C BDへの一籼化費用

以下に、各指標の定義を示す。なお、各メッシュから 駅までは徒歩 (時速 $4 \mathrm{~km} / \mathrm{h}$ ) でアクセス寸るものとした。 待ち時間は列車運行間隔の半分とし、乗換え時間は乗換 え駅相互での徒歩による所要時間とした。時間評価値は、

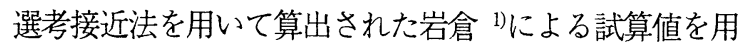
いている。

\section{(1) メッシュ i から CBD までの一般化頙用}

$G C_{i}=A C T_{i} \cdot A C T V+L H T_{i} \cdot L H T V$

$+W A T_{i} \cdot W A T V+E G T_{i} \cdot E G T V+F_{i}$

ここで

$G C_{i}$ :メッシュiから CBD までの一般化費用（円）

$A C T_{i}$ : メッシュ $i$ から駅までのアクセス時間 (分)

$L H T_{i}$ : 乗車時間 (分)

$W A T_{i}$ : 待ち時間・乗換之時間 (分)

$E G T_{i}$ : 駅から CBD までのイグレス時間 (分) 
EGTV：イグレス時間の評価值 (40円/分)

LHTV：乗車時間の評価值（26円份）

$A C T V$ : アクセス時間の評価值 (33円/分)

WATV : 待ち時間 - 乗換え時間の評価值 (45 円/分)

$F_{i}:$ 鉄軌道の運顀 [普通 $] \cdot$ 料金 (円)

\section{(2) 平均一籼化冥用}

$$
A V G \cdot G C=\sum_{i}\left(G C_{i} \cdot P O P_{i}\right) / \sum_{i} P O P_{i}
$$

ここで

$A V G \cdot G C$ : 平均一般化費用 (円)

$P O P_{i}:$ メッシュ i の人口 (人)

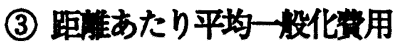

$A V G \cdot G C L=A V G \cdot G C / D I S T$

ただ

$D I S T=\sum_{i}\left(D I S T_{i} \cdot P O P_{i}\right) / \sum_{i} P O P_{i}$

ここで
$A V G \cdot G C L$ ：距離あたり平均一般化費用 (円 $/$ 人 $\cdot \mathrm{km}$ )

DIST : CBD までの平均距離 $(\mathrm{km})$

$D I S T_{i}$ :メッシュiからCBDまでの距離 $(\mathrm{km})$

参考までに、札幌都市圈を例にとって、人口分布構造、 鉄軌道ネットワーク及び CBD を目的地として試算した 一般化費用コンターを図ー4に示す。

上記の定義による距離あたり平均一般化費用によって 都市鉄道整備水準を表現することにより、次に示す改善 が期待される。

1）メッシュデータの活用により、都市圈内の人口分 布と鉄軌道ネットワークとの近接性（都市圈構造 とその構造に対応した鉄軌道ネットワークの充足 度）が表現できる。

2）列車ダイヤ・乗り継ぎ利便性、運賃を取り込むこ とにより、高速性、フリークエンシー、乗換え利 便性、低廉性等のソフト面でのサービス水準を表 現できる。

3）各都市圏の大きさの違いを考慮した地域間比較分 析等により、目標水準の設定が可能になる。

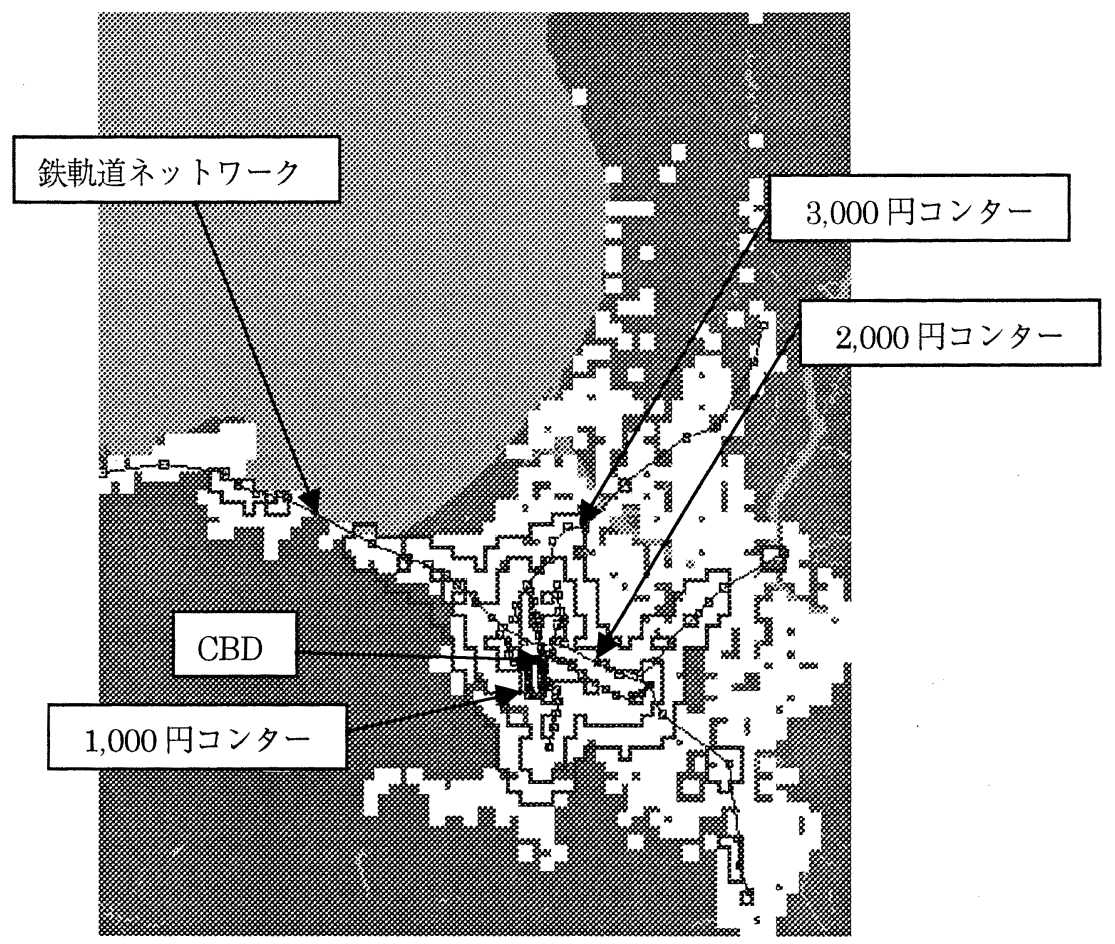

注：図中の白ヌキの部分は札幌都市圈ての可住地を示している。

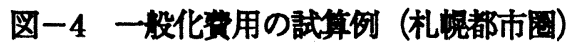




\section{（3）指標の有効性}

人口 50 万人以上の 29 都市圈を対象に、距離あたり 平均一般化費用を算出した。

各都市圈における距離あたり平均一般化費用と鉄軌 道分担率とを比較したものが図一 5 である。一般化費 用は、鉄軌道利用による所要時間と運賃 ·料金で構成 されている。その值は高ければ高いほど鉄軌道利用に 際しての抵抗となっていくため、一般化費用と鉄軌道 分担率とは負の相関を有している。ただし、図中に示

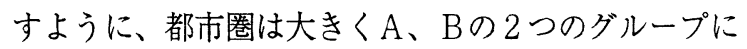
区分した。前者は JR 中央駅が CBD に該当するメッシ ユに含まれていない都市圈である。後者は、北九州、 静岡、浜松、福山等 JR 中央駅周辺に CBD が発達して いる都市圈である。A グループの都市圈は、多くの旅 客が集中する JR 中央駅から CBD までのイグレスがあ るために、B グループの都市圈と比較して一般化費用 が高い值を示す傾向にある。後述の回帰分析において は、この両グループの違いをダミー処理している。鉄 軌道分担率を被説明変数とし、距離あたり平均一般化 費用を説明変数として回帰分析を行った結果を次に示 す。両指標はいずれも自然対数をとっている。

$$
\begin{aligned}
\ln (R R)=10.11574 & -2.20731 \quad \times \ln (G C L) \\
(5.5387) & (-6.8482) \\
& -0.54637 \\
(-3.9283) & \times D U M M Y
\end{aligned}
$$

$R=0.8062 \quad R^{2}=0.6500$

()内は $\mathrm{t}$ 值

ここで

$R R$ : 鉄軌道分担率

$G C L$ ：距離あたり平均一般化費用 (円/人 $k m$ )

$D U M M Y$ ：イグレス補正ダミー(JR 中央駅から CBD までのイグレスがある都市圏は 0 , ない都 市圏は 1)

上記の関係式(1)を書き換えると

$$
\begin{aligned}
& R R=24729.2 \times G C L^{-2.20731} \quad(\text { グループA }) \\
& R R=14319.4 \times G C L^{-2.20731} \quad(\text { グループ } \mathrm{B})
\end{aligned}
$$

ある。ここで、グループ Aとグループ Bの鉄軌道分担 率が一致する場合、両グループの一般化費用の間には 次の関係が成り立つ。

$$
G C L_{B} / G C L_{A}=0.780729
$$

ですなわち、(2)式の值はグループ Aに属する都市圏と グループBに属する都市圏との間で鉄軌道整備水準を 比較する際の調整係数となる。

さて、回帰分析の結果、鉄軌道分担率と距離あたり 平均一般化費用の相関は 0.81 となった。図一 2 に示す 人口あたり駅数に比較して、鉄軌道分担率との相関が 改善される結果となっている。

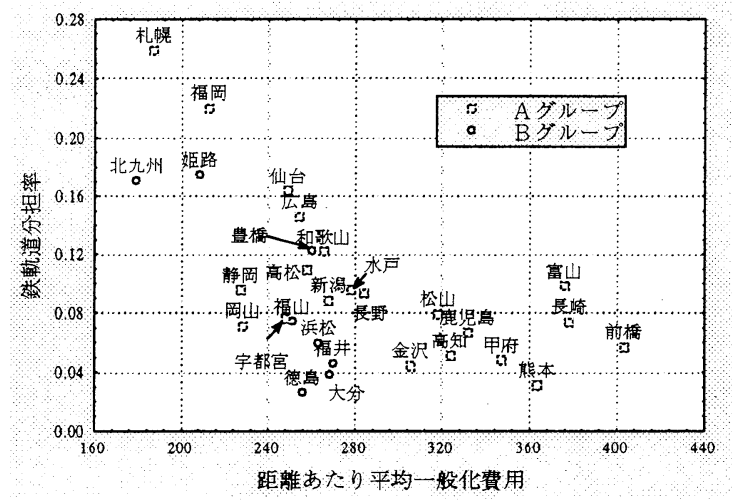

\section{図ー5 距就あたり平均一般化費用と 鉄軌道分担率との比較}

\section{（4）的測㷬果（都市圈ランキング）}

各都市圏における距離あたり平均一般化費用を図一 6 に示す。算出にあたっては、(2)式に示した調整係数を 用いてグループAとグループBの間の調整を行ってい る。これらの值は、都市圏における都市鉄道整備水準 を総合的に表現しており、いわば都市鉄道の整備水準 にかかる都市圏ランキングともいえるものである。29 都市圈の中で最も整備水準の良好な都市圏は、距離あ たり平均一般化費用が 187.1 円 $/ k m$ で最も低い札幌とい う結果になった。一方、最も整備水準が低い都市圏は、 402.9 円 $/ \mathrm{km}$ の前橋という結果になった。

距離あたり平均一般化費用を総合指標とみなすと、そ れは大きく 4 つの要素で構成されている。「駅までのア クセス・イグレス時間」「乗車時間」「待ち時間・乗換 え時間」「運貨・料金」である。このような各要素に着 目すると、各都市圈の強み・弱みを把握することがで きる。本研究では、これら 4 つの要素を示す指標とし て、住民 1 人あたりの「駅までのアクセス距離（アク 七ス利便性)」「平均列車速度 (高速性)」「待ち時間 乗換え時間比率（フリークエンシー・乗換え利便性）」 「キロあたり運貨（低廉性）」に着目し、都市圈におけ 


\section{る各要素について整備水準の試算を行った。距離あた}

り平均一般化費用の小さい順に結果を示すと表一1の

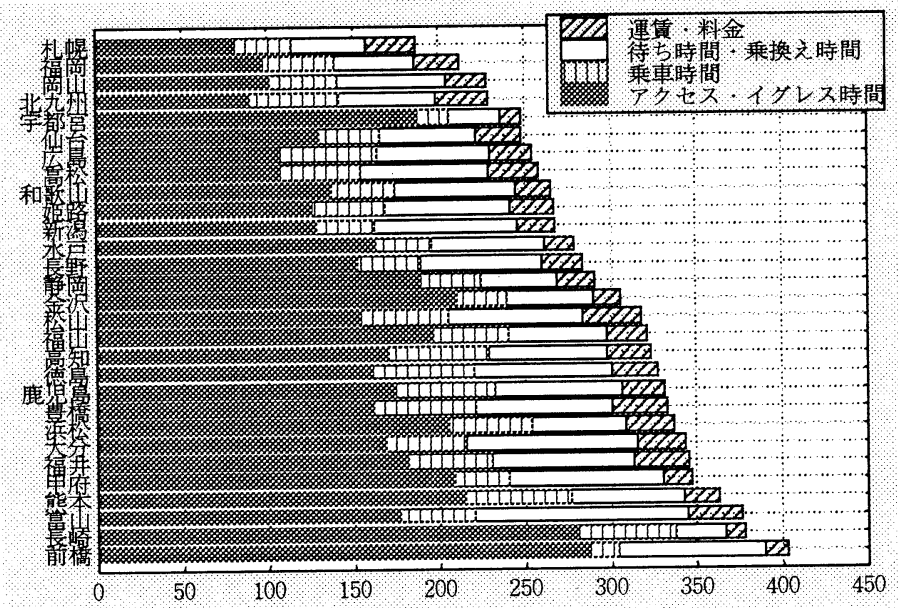

注：グループBの距離あたり平均一般化費用の算出にあたっては、(2)式に示した調整係数を用いて調整を行っている。

図一6 CBD までの距㕍あたり平均一般化费用

（都市鉄道整倨水準にかかる都市圈ランキング）

\section{表一 1 要素别整俏水準（住民 1 人あたり平均值）}

\begin{tabular}{|c|c|c|c|c|}
\hline 都市圈 & $\begin{array}{r}\text { 駅までの } \\
\text { アクセス距離 } \\
(\mathrm{km})\end{array}$ & $\begin{array}{r}\text { 平均列車速度 } \\
(\mathrm{km} / \mathrm{h})\end{array}$ & 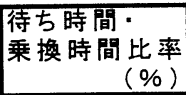 & \begin{tabular}{|r|} 
キロあたり \\
運貨 \\
$($ ( $/ \mathrm{km})$
\end{tabular} \\
\hline 札幌 & 1.73 & 38.9 & 42.9 & 43.5 \\
\hline 福岡 & 2.16 & 37.0 & 39.4 & 33.7 \\
\hline 岡山 & 2.76 & 41.8 & 47.9 & 27.0 \\
\hline 北九州 & 1.76 & 45.5 & 38.6 & 25.0 \\
\hline 宇都宮 & 3.59 & 59.5 & 48.1 & 19.6 \\
\hline 仙台 & 2.75 & 36.9 & 48.0 & 40.9 \\
\hline 広㗐 & 2.46 & 27.7 & 40.1 & 31.6 \\
\hline 高松 & 2.00 & 34.9 & 48.6 & 33.4 \\
\hline 和歌山 & 1.62 & 41.2 & 52.2 & 26.5 \\
\hline 姫路 & 1.98 & 49.9 & 50.3 & 23.7 \\
\hline 新潟 & 2.59 & 44.6 & 59.4 & 25.0 \\
\hline 福井 & 2.66 & 41.9 & 49.7 & 27.7 \\
\hline 水声 & 2.96 & 50.5 & 54.2 & 20.0 \\
\hline 長野 & 2.59 & 39.5 & 52.8 & 31.4 \\
\hline 静岡 & 2.61 & 49.5 & 42.5 & 23.8 \\
\hline 金沢 & 2.31 & 39.0 & 49.9 & 25.7 \\
\hline 松山 & 1.77 & 26.9 & 47.3 & 44.4 \\
\hline 福山 & 3.01 & 52.7 & 42.5 & 20.0 \\
\hline 高知 & 3.47 & 19.2 & 40.1 & 74.0 \\
\hline 德息 & 2.28 & 33.6 & 43.5 & 23.9 \\
\hline 鹿児易 & 2.81 & 21.3 & 42.3 & 41.4 \\
\hline 豊橋 & 1.55 & 37.3 & 43.4 & 30.4 \\
\hline 浜松 & 2.63 & 42.3 & 39.9 & 26.5 \\
\hline 大分 & 2.61 & 43.7 & 55.1 & 22.8 \\
\hline 甲府 & 2.90 & 48.7 & 62.2 & 21.1 \\
\hline 熊本 & 3.59 & 18.1 & 38.0 & 31.0 \\
\hline 富山 & 2.89 & 34.7 & 62.0 & 34.4 \\
\hline 長崎 & 3.84 & 15.2 & 22.8 & 20.6 \\
\hline 前橋 & 3.86 & 53.8 & 73.8 & 27.7 \\
\hline
\end{tabular}

1)一籼化費用を取小にする駅までのアクセス距離

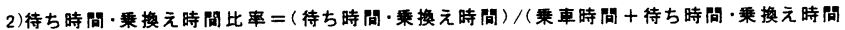


総合で上位の都市圏は、概ねアクセス利便性に優れ ている。宇都宮は、駅までのアクセス距離では $3.59 \mathrm{~km}$ で相対的に劣っているものの、高速性や低廉性でカバ 一して上位に位置している。一方で、下位に位置する 都市圏は、アクセス利便性とともに、フリークエンシ 一・乗換え利便性の水準が低い都市圈が多い。長崎は、 100 円均一運貨で運行される路面電車が長崎市内の基 幹交通となっており、フリークエンシー・乗換え利便 性や低廉性では優れた水準を示しているが、都市圈全 体でのネットワーク不足や路面電車の表定速度が低い ために、アクセス利便性や高速性の水準が低く、総合 的な評価では下位に位置している。

各都市圏の強み・弱みをより明確に把握する場合は、 次に示すレーダーチャートによる表現が適している。

最も整備水準が高い札幌と最も低い前橋の両都市圈 について、個別要素ごとに整備水準を表現したものが 図-7である。各要素ごとの值は、29 都市圈の平均と 標準偏差を用いて基準化した上で、最も高い整備水準 を示す都市圈の值が「5」、最も低い整備水準を示す都 市圏の值が「0」となるように調整している。

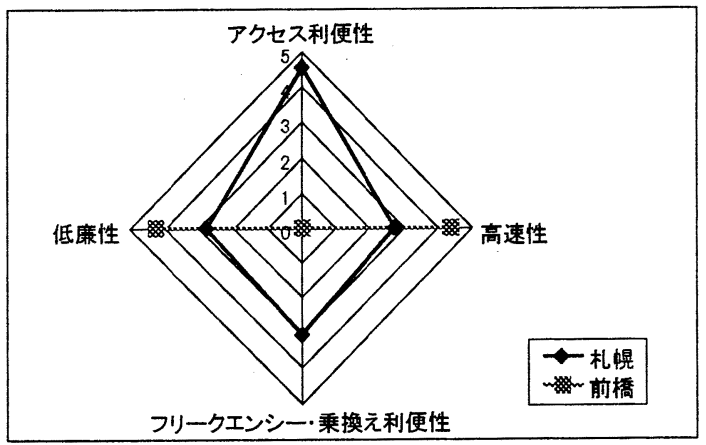

注 1 : 個別要素を表す指標は次のとおり。いずれも住民 1 人当たりの平 均値である

\begin{tabular}{|c|c|}
\hline アクセス利便性 & 駅までのアクセス距離 \\
\hline 高速性 & 表定速度 \\
\hline $\begin{array}{l}\text { フリリークエントー・乗換之利便性 } \\
\text { 低廉性 }\end{array}$ & $\begin{array}{l}\rightarrow \text { 待ち時間 } \cdot \text { 乗換え時間比率 } \\
\rightarrow \text { キロ当たり運賃 }\end{array}$ \\
\hline
\end{tabular}

注 2 : 待ち時間·乗換之時間比率

= (待ち時間·禿換之時間)）（乗車時間十待ち時間・乗換之時間）

図一 7 要素別整佣水準の評価

結果についてみると、札幌は、アクセス利便性を筆 頭に、各要素ともに平均以上の水準を示している。こ れに対して前橋では、特にアクセス利便性とフリーク エンシー・乗換え利便性が 29 都市圈中で最低水準に あり、これが総合的な評価を下げる要因になっている。

\section{（5）国察間での試算・比㜞}

都市圏構造および都市鉄道ネットワークに関するデ ー夕がそろえば、日本の諸都市圏と海外の都市圏との 間で、都市鉄道の整備水準を試算・比較することも可 能である。

ここでは、都市圈人口で 100 万人台から 200 万人台 の札幌、仙台、広島、福岡とドイツのフランクフルト との間で、都市鉄道の整備水準を比較した。たたし、 デー夕制約上、都市圏ベースではなく都市ベースでの 比較となっている。フランクフルトでは、メッシュデ 一夕がないため、調査区のデータを代用している。調 査区の平均面積は $1.9 \mathrm{k} \mathrm{m}^{2}$ で日本のメッシュデー夕より も大きいため、フランクフルトにおけり「駅までのア クセス距離」は、日本のそれに比べて長い值を示す方 向にバイアスがかかる。したがって、フランクフルト における一般化費用は、日本の諸都市に扔ける一般化 費用に比べて大きな值を示す方向にバイアスがかかる 点に留意されたい。

距離あたり平均一般化費用を比較した結果を図ー8 に示す。フランクフルトの距離あたり平均一般化費用 が唯一 200 円 $/ \mathrm{km}$ を下回っており、最も低い。アクセ ス利便性に関して大きな值を示す方向にバイアスがか かっているにもかかわらず、フランクフルトは距離あ たり平均一般化費用において日本の諸都市を下回って おり、他の日本の諸都市に比較して良好な都市鉄道整 備水準を有しているものと試算された。

要素別に整備水準を比較したものが表一 3 である。 全ての項目について、フランクフルトは他の日本の諸 都市に比較して良好な水準を示している。特に、アク セス利便性を示す「駅までのアクセス距離」は、住民 1 人あたり平均 $590 \mathrm{~m}$ で非常に優れた水準を示してい る。ドイツ鉄道によるSバーンと日本の諸都市におけ る J Rの整備延長はほほ同程度であるため、アクセス 距離の差は、地下鉄に相当するUバーンと路面電車の 路線延長の違いによるところが大きい。また、フリー クエンシー・乗換え利便性を示す「待ち時間・乗換え 時間比率」でもフランクフルトは良好な水準を示して いるが、これは、統合ダイヤを導入するなど、運輸連 合を設立することによって事業者間調整を行っている こと等の成果である。

このように要素ごとに試算・比較を行えば、より具 体的な項目ごとに整備水準の乘離状況を数值で確認す ることができる。 


\section{表一2 比媑対象都市}

\begin{tabular}{|c|c|c|c|c|c|c|}
\hline & フランクフルト & 札幌 & 仙台 & 広島 & \multicolumn{2}{|c|}{ 福岡 } \\
\hline $\begin{array}{l}\text { 人口(千人) } \\
\text { [都市圏人口] }\end{array}$ & $\begin{array}{c}653 \text { 千人 } \\
{[2,600 \text { 千人 }]}\end{array}$ & $\begin{array}{r}1,671 \text { 千人 } \\
{[2,107 \text { 千人 }]}\end{array}$ & $\begin{array}{r}918 \text { 千人 } \\
{[1,436 \text { 千人 }]}\end{array}$ & $\begin{array}{r}1,086 \text { 千人 } \\
{[1,759 \text { 千人 }]}\end{array}$ & \multicolumn{2}{|c|}{$\begin{array}{r}1,237 \text { 千人 } \\
{[2,175 \text { 千人 }]}\end{array}$} \\
\hline 可住地面積 & $248 \mathrm{~km}^{2}$ & $473 \mathrm{~km}^{2}$ & $328 \mathrm{~km}^{2}$ & $508 \mathrm{~km}^{2}$ & & $289 \mathrm{~km}^{2}$ \\
\hline 路線延長 & $\begin{array}{l}\text { Sバーン } 65 \mathrm{~km} \\
\text { Uバーン } 56 \mathrm{~km} \\
\text { 路面電車 } 63 \mathrm{~km}\end{array}$ & $\begin{array}{lr}\text { JR } & 54.5 \mathrm{~km} \\
\text { 地下鉄 } & 45.2 \mathrm{~km} \\
\text { 路面電車 } & 8.5 \mathrm{~km}\end{array}$ & $\begin{array}{lr}\text { JR } & 69.1 \mathrm{~km} \\
\text { 地下鉄 } & 14.8 \mathrm{~km}\end{array}$ & \begin{tabular}{|lr}
$\mathrm{JR}$ & $105.7 \mathrm{~km}$ \\
広電郊外 & $8.7 \mathrm{~km}$ \\
路面電車 & $18.8 \mathrm{~km}$ \\
新交通 ${ }^{* 1}$ & $18.4 \mathrm{~km}$ \\
\end{tabular} & $\begin{array}{l}\text { JR } \\
\text { 西鉄 } \\
\text { 地下鉄 }\end{array}$ & $\begin{array}{r}68.0 \mathrm{~km} \\
8.5 \mathrm{~km} \\
17.8 \mathrm{~km}\end{array}$ \\
\hline 計測単位 & $\begin{array}{c}\text { 調査区 } \\
\left(\text { 平均 } 1.9^{* 2} \mathrm{~km}^{2} \text { ) }\right.\end{array}$ & \multicolumn{5}{|c|}{ 国勢調査による基準地域メッシュ (1 km メッシュ) } \\
\hline
\end{tabular}

※1 広島市の新交通システムは1990年時点では開業していない

※2 空港地区を除く平均面掼である

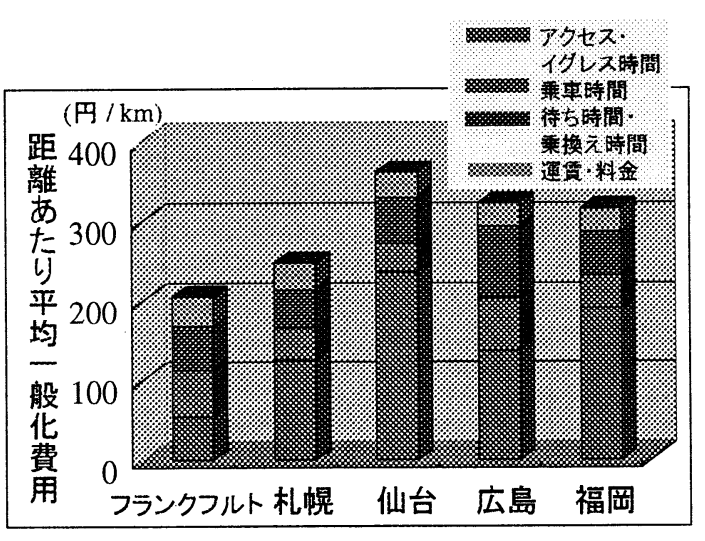

図-8 試算䊅果

\section{表-3 個別要素别試算結果}

\begin{tabular}{|c|c|c|c|c|c|}
\hline & $75 \% 174$ & 札幌 & 化台 & 広酉 & 福㷙 \\
\hline $\begin{array}{l}\text { 駅まくのアクセマ距離 } \\
(\mathrm{m})\end{array}$ & 590 & 1710 & 2410 & 1840 & 2300 \\
\hline 平均列車速度 & 35.4 & 33.6 & 30.3 & 20.6 & 32.4 \\
\hline $\begin{array}{l}\text { 待 } 5 \text { 時間・乗換時間比率 } \\
(\%)\end{array}$ & 34.3 & 41.1 & 49.6 & 43.5 & 43.4 \\
\hline $\begin{array}{c}\text { キロあたり運賃 } \\
\text { (円 / / m })\end{array}$ & 39.2 & 49.4 & 56.7 & 40.1 & 41.8 \\
\hline
\end{tabular}

注:待ち時間·乗換時問比率＝待ち時間·乗換え時間／(乗車時間一待ち時間·乗換え時間)
化を図っていく上では、まず自らのポジションを客観 的に認識した上で、目標水準を設定し、その達成に向 けて具体的な施策を立案・実施していくことが重要で ある。今回提案した指標は、概念的に新しいものでは ないが、メッシュデータを用いて都市圈内の人口分布 構造を反映した指標化を行うことにより、より実態に 近い都市鉄道整備水準の表現が可能になったと考えて いる。また、一般に欧州の地方都市圈の都市鉄道は日 本に比較して整備水準が高いと考えられているが、フ ランクフルトと札幌、仙台、広島、福岡において都市 鉄道整備水準を試算・比較することにより、乘離状況 を数值で確認した。

この指標の活用方向としては、都市圈間比較により 各都市圈に推ける目標水準の設定や弱点の把握を支援 すること、及び具体的な都市鉄道整備施策を実施する 場合に都市鉄道整備水準の改善効果を計測することな どがあげられよう。

今後は、新線建設や列車の増発等具体的な施策によ る改善効果の計測にこの指標を適用していき、実務へ の応用を図っていくことが必要と考えている。また、 収集·整㣁したメッシュデータを活用することにより、 複数の都市圈、複数の路線沿線を対象として、都市鉄 道が成立するために駅勢圈が満たすべき条件について 分析していきたいと考えている。

\section{3. おわりに}

地方都市圈が都市鉄道をはじめとする公共交通の強 


\section{参考文献}

1）岩倉：市場、行動および意識デー夕を用いた都市鉄道整備の効果予 測法に関する研究、東京工業大学学位論文、pp.56-61、1994

2）蓼沼・清水・高久：GIS を用いた鉄道新線の利用者便益の試算につ いて、土木計画学研究・講演集 No.19(2)、pp.725-728、1996

3）谷口 - 石田 · 小川 - 黑川：通勤 - 通学交通手段利用率の変化と都市 特性の関連に関する基礎的研究、土木計画学研究・論文集 No.12、 pp443-451、1995
4) 平石・貓沼：都市鉄道整備水準評価指標に関する基礎的考察、土木 計画学研究·講演集 No.20(2)、pp239-242、1997

5）金森·荒·森口編：有斐閣経済辞典、pp 486-487、1971

6) Stadt Frankfurt am Main : Materialien zur Stadt-beobachtung, Die Frankfurter Ortsteile und Stadtbezirke Statistische Profile 1987-1995

7) Stadtwerke Frankfurt am Main GmbH : Fahrplan \& Gesamtlinienplan、 1996

8) Rhein-Main-Verkerhrsverbund : The Mobility of the Future, 1995

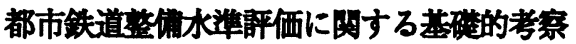

\section{平石 和昭、蓼沼 慶正}

概要

海外、特に欧州の諸都市圏に比較して、日本の地方都市圏の都市鉄道整備水準は低い。地方都市圏にお いて都市鉄道サービスを改善するための問題点の一つとして、投資の目安となる適切な整備水準指標がな いことが指摘できる。そこで、地方都市圏における交通政策上の重要な課題である CBD へのアクセスに 着目し、一般化費用概念に用いて、都市鉄道整備水準を表す新たな指標の提案を行い、50 万人以上の 29 地方都市圏を対象としてその有効性の検討を行った。さらに、この指標を用いて、札幌、仙台、広島、福 岡とドイツのフランクフルトとの間で都市鉄道整備水準の試算・比較を行い、目標水準設定に関する検討 を行った。

\section{A Basic Study on the Indicator for measuring Services and Infrastructure Developments of Urban Railways}

Kazuaki HIRAISHI, Yoshimasa TADENUMA

\begin{abstract}
In local metropolises, the congestion rate is not an accurate indicator of the performance of urban railway services. The absence of an accurate indicator is the major obstacle to investment of railways. So, we have given attention to the access to the CBD and proposed the indicator for measuring services and infrastructure developments of urban railways. We have calculated this indicator for 29 Japanese local metropolises and tested validity by the analysis of correlation with the modal share of railways.
\end{abstract}

